\title{
PERSONAL AND SYSTEM REQUIREMENTS OF A SUCCESSFUL RESEARCHING CAREER IN THE FIELD OF MULTIDISCIPLINARY BIOMEDICAL SCIENCES - PERSONAL REVIEW / OVERVIEW
}

\author{
Đorđe Jakovljević \\ Cardiovascular Research Centre, Institute of Cellular Medicine, Faculty of Medical Sciences, Newcastle University, \\ and Newcastle upon Tyne Hospitals NHS Foundation Trust, United Kingdom
}

\begin{abstract}
A multidisciplinary approach to scientific research is necessary in order to find answers to complex questions in the field of medical and biomedical sciences. The author of this paper is a member of and coordinates the work of a multidisciplinary team composed of medical specialists, general practitioners, molecular biologists, biochemists, physiologists, psychologists, physiotherapists, bioinformaticians, physicists, statisticians and engineers. The team has been managed a research program over the previous several years in the following areas: cardiovascular ageing, heart failure and physical activity. The aim of this review article was to present the findings of several research projects and papers published in renowned international scientific journals in the areas of: I) studying the process of cardiovascular ageing, its impact of physiological processes and interaction with physical activity, and II) improving the diagnosis and treatment of heart failure in primary and secondary health care. Overall aim of the research programme has been twofold; I) to improve general health and functional capacity of older people and patients, and II) to improve health care system and clinical practice. In addition to a brief presentation of the scientific papers and their findings, this review article will also desrbibe ways of securing research funding and grant application procedures required for the research within the higher education system in the United Kingdom.
\end{abstract}

Key words: MULTIDISCIPLINARY APPROACH / BIOMEDICAL SCIENCES / CARDIOVASCULAR DISEASES / HEART FAILURE / PHYSICAL EXERCISE / RESEARCH / UNITED KINGDOM

\section{INTRODUCTION}

A multidisciplinary approach is required in order to find the answers and solutions to complex research questions in the fields of medical and biomedical sciences. Multidisciplinarity implies the involvement (engagement) of several academic disciplines and professional specialties in addressing and solving a pre-defined problem (Youngblood, 2007). New, multidisciplinary approaches are necessary to meet many, if not all, scientific and research as well as economic and social challenges of today. It is obvious that only such an approach can contribute to the innovations promoting the economic development, psychophysical and social well-being of the citizens and systems of both developed and developing countries. There is an outstanding example of the Research Councils UK with the annual budget of more than $£ 3$ billion in research covering the full spectrum of academic disciplines from the medical and biological sciences to astronomy, physics, chemistry and engineering, social sciences, economics, environmental sciences and the arts and humanities. (Harper; Walport, 2016).

One of the greatest challenges facing mankind in the next 30-50 years will be a drastic change in the population demographic structure, predicting that by 2050 , one in three people will be $>65$ years old, and one in 10 people will be $>80$ years old (Lakatta, Levy, 2003). These changes are of tremendous economic 
and social significance. Responding to the demographic changes will require the adaptation of many aspects of people's lives, including the way we work, take care of, communicate and "interact" with others, adjust the immediate environment where we live and work, learn and use technology. In order to adapt to such conditions successfully, it is necessary to understand the nature and implications of the demographic changes as well as the details of the biological ageing process itself.

From the point of view of medical and biomedical sciences, it is necessary to understand the molecular, cellular and physiological changes which directly affect the ageing process of humans. These changes result in a decline in quality of life, functional capacity, and lowering the threshold for the occurrence of chronic diseases which contribute to an increased mortality and morbidity in the elderly. The author of this article is a member and leader of the multidisciplinary team composed of medical specialists, general practitioners, molecular biologists, biochemists, physiologists, psychologists, physiotherapists, bioinformaticians, physicists, statisticians and engineers.

The task of this multidisciplinary team is to enhance the understanding of the ageing process with a particular emphasis on cardiovascular and metabolic changes and to identify potential therapeutic pharmacological and physiological interventions which will improve the quality of life and function of the elderly, slow down the ageing process, and affect the prevention of chronic diseases.

The aim of this review article was to present the findings of several scientific and research papers of the specified multidisciplinary team in the fields of: I) studying the process of cardiovascular ageing and its interaction with physiological interventions, and II) improving the diagnosis and treatment of heart failure in primary and secondary health care.

\section{Cardiovascular system ageing and physical activity}

The age of an individual is a major risk factor for the occurrence of cardiovascular diseases, which are the leading cause of mortality and morbidity in the elderly in developed countries (Harper, Walport, 2016). In the absence of clinical hypertension or a diagnosed cardiovascular disease, structural and functional changes in the heart and blood vessels result from the ageing process (Lakatta, Levy, 2003). These changes lower the threshold of the occurence of clinical symptoms and signs associated with cardiovascular diseases (Shih et al, 2011). Magnetic resonance imaging of the heart and blood vessels is one of the leading non-invasive methods of evaluating the structure and function of cardiovascular system (Hollingsworth, 2012).

Physical activity plays an important role in the prevention and management of cardiovascular diseases (Chodzko-Zajko et al, 2009; Berry, 2013). Regular physical activity reduces the rate of overall and cardiovascular mortality between 30-40\% (Shiroma, Lee, 2010; Blair et al, 1995; Talbot et al, 2007). On the other hand, people who are physically inactive show a $63 \%$ greater risk of developing cardiovascular diseases (Chomistek, 2013). Despite the fact that physical activity plays a very important role in maintaining general health and cardiovascular function, the ageing process leads to a decline in physical activity and cardiovascular function (Talbot, Metter, Fleg, 2000; Wilson \& Tanaka, 2000; Tanaka et al, 1997).

Although regular physical activity can attenuate physiological, molecular and cellular process associated with ageing,, as indicated recently in a review article (Jakovljevic, 2017), further research is necessary to define the details of the interaction between the ageing process, physiological function and physical activity. In a previous study, we examined the correlation between cardiac function and vascular (arterial) function in relation to the age (Houghton et al, 2016). The results have shown that arterial stiffness is an excellent indicator of the cardiac function in the older, but not in younger age.

It is also necessary to determine molecular mechanisms as potential causes of heart function deteoriation with ageing.. A study we have recently published confirmed the role of cardiac energy metabolism (high-energy phosphate metabolism measured by magnetic resonance spectropsopy) in preserving the cardiac function in the elderly (Nathania et al, 2017). The results of these studies have influenced the development of new ideas and research projects aiming to identify new pharmacological and physiological interventions which will reduce arterial stiffness and/ or enhance cardiac energy metabolism in order to improve the myocardial systolic and diastolic function.

Daily physical activity can be objectively measured 
using accelerometers and pedometers in research and clinical practice. According to the results of previous research, and based on an average number of steps taken by an individual, respondents can be categorized as 'low physically active' ( $<7.500$ steps per day) or 'very physically active' ( $>12,500$ steps per day) (Tudor-Locke, Bassett, 2004). Using this approach, we have quantified the effect of the objectively measured physical activity on the changes in cardiac function, structure and metabolism resulting in relation to physiological ageing (Jakovljevic et al, 2015). In a single-center cross-sectional study involving 63 participants (female), the results have shown that a high level of daily physical activity is required to preserve cardiac metabolism and functional capacity represented by cardiorespiratory fitness, i.e. maximum oxygen consumption. However, another study indicated that an increased level of physical activity actually has limited effect on the reduced cardiac autonomic function in the elderly (Njemanze et al, 2016).

In addition to the described clinical studies, we also lead the research program of basic sciences applying the experimental methods which involve mice. This program allows us to define the molecular and cellular mechanisms responsible for a reduction in physiological function due to the ageing process, using the heart muscle tissue (myocardium) itself, large arteries, the central nervous system, skeletal muscles, and other organs, thus enabling the identification of new goals for the development of pharmacological and physiological therapeutic strategies. We are especially focused on better understanding of the changes in and the role of mitochondria, as unique but very complex organelles responsible for a whole range of energy processes occuring at the cellular level as well as for the proper functioning of cells, organs and organisms themselves.

In order to unify and synchronize scientific research in the field of clinical and basic sciences regarding the study of the ageing process and the impact of physiological and pharmacological effects on it, in 2015 we created a project, applied for and received the funding from the UK Medical Research Council in the amount of $£ 5.5$ million for a period of 5 years (2016-2021), which enables the research and functioning of the Center for the Study of the Aging Process within which the author of this article leads the field of cardiovascular research.

\section{HEART FAILURE - FROM DIAGNOSIS IMPROVEMENT, THE EFFECT OF PHYSICAL EXERCISE ON PATIENT OUTCOMES TO MECHANICAL CIRCULATORY SUPPORT AND COMPLETE RECOVERY}

\section{Early diagnosis of heart failure}

Heart failure or cardiac insufficiency is a clinical syndrome accompanied by the symptoms and signs caused by structural and/or functional abnormalities of the heart which result in a decrease in cardiac output at rest or under stress (Ponikowski et al, 2016). The prevalence and incidence of heart failure increase linearly due to the changes in demographic structure and the improved outcome in coronary artery diseases. Over $2 \%$ of the population aged $>45$ have heart failure, and the prevalence exceeds $>10 \%$ in the population over 70 (Ponikowski et al, 2016). Heart failure is associated with a very poor prognosis (5-year mortality rate is $42 \%$ ), frequent hospitalization and high medical costs (Hobbs et al, 2007).

Early diagnosis of heart failure is crucial because it allows the implementation of a therapy which reduces mortality and morbidity, while improving the quality of life and functional capacity in patients (Ponikowski et al, 2016). However, the diagnosis is complicated and imprecise, especially in the early stages of the disease. Even though the patients seek medical help due to the symptoms they have, many of these symptoms and signs need not be associated only with the reduced cardiac function, but also with age, obesity or respiratory problems (Mant et al, 2009). General practitioners play a key role in the early detection of heart failure (Hobbs et al, 2010). However, medical research has shown that heart failure is difficult to identify in primary care, thus patients are not referred to specialists when this is optimal, but very often in later stages of the disease (Hobbs et al, 2010; Roberts et al, 2015). The main reason for such situation is that heart failure is recognized as a complex disease presented with cardiac dysfunction, and general practitioners do not have access to the simple, relatively inexpensive methods which they can apply in their practice to evaluate cardiac function which will help them diagnose and monitor heart failure (Fonseca 2006; Fuat, Hunigain, Murphy, 2003).

In addition to evaluating symptoms and signs, general practitioners currently have access to (use) an 
electrocardiogram and analyze biomarkers, such as B-type natriuretic peptide. However, the diagnostic precision of both methods has been reduced (Roberts et al, 2015; Khunti et al, 2004). The reduced precision of these tests also affects late diagnosis as well as inaccurate referrals from primary to secondary care which are very expensive for the health care system (42 million pounds per year) and worrying for the patients.

Heart ultrasound (echocardiography), performed in secondary care, and specialist examination is a reference method applied to diagnose heart failure (Ponikowski et al, 2016). However, waiting times for echocardiographic examination may be up to 12 weeks (Commission, 2007), which results in late diagnosis. On the other hand, $2 / 3$ of the patients referred from primary to secondary care on the basis of the biomarker results, symptoms and signs do not have a confirmed diagnosis of heart failure after the echocardiography and specialist examination performed. Therefore it may be observed that there is a strong need to identify new modern diagnostic methods which will lead to the improvement of clinical practice in primary care and the good patient outcomes in regard to the early detection (diagnosis) of heart failure.

Bearing in mind the aforementioned facts, we have developed a simple, non-invasive test which implies the continuous measurement of cardiac function (cardiac output) at rest and during a cardiac stress test (CORS, cardiac output response to stress test) using a method for estimating cardiac function based on electric signal processing (bioreactance). In our previous research we previously confirmed validity and reliability of bioreactance method for monitoring cardiac function at rest and during stress exercise (Jakovljevic et al, 2012; Jakovljevic, Trenell \& MacGowan, 2014; Okwose et al, 2017; Perkins et al, 2016; Jones et al, 2015). The CORS test has been developed for the purposes of primary care and with the aim to enhance early diagnosis and improve the accuracy of referrals from primary to secondary care. The researchers engaged in the ongoing program focus on the diagnostic precision (sensitivity and specificity) of the CORS test, its acceptability by patients, general practitioners and medical technicians. The initial phase of this research program has been funded by the UK Medical Research Council (MRC) in the amount of $£ 220,000$ for the period 06/2016-03/2018. In cooperation with the Directors of the Departments of Public Health and Primary Care Research at the Universities of Oxford and Cambridge, the applications for the UK National Institute of Health Research (NIHR) worth $£ 2.3$ million are being prepared for a five-year research multi-center program aiming to confirm the diagnostic precision of the CORS test on a large sample size, its economic evaluation as well as the implementation of the CORS test and the clinical practice of primary care.

\section{The role of physical activity in heart failure}

Clinical guidelines suggest physical activity to be integrated into rehabilitation program as one of the main components of heart failure management (Ponikowski et al, 2016). Meta-analyses have shown that regular physical activity improves functional capacity and quality of life, at the same time affecting the reduction of symptoms and hospitalization in heart failure patients (Davies et al, 2010; Piepoli et al, 2011; Lewinter et al, 2015). Also, physical activity may, to some extent, affect the improvement of cardiac function itself when heart failure has been already diagnosed (Haykowsky et al, 2007; Mezzani, Corra \& Giannuzzi, 2008).

Although the benefits of physical activity in heart failure have been clearly defined, it is known from clinical practice that most patients show a reduced level of regular physical activity (which is directly associated with morbidity and mortality rate) (Walsh et al, 1997; Sato et al, 2012; Jehn et al, 2009). Despite clear recommendations, very few patients with heart failure $(<10 \%)$ participate in the rehabilitation programs organized by the health care system due to a lack of resources and the direct exclusion of heart failure rehabilitation programs from commissioning agreements (Dalal et al, 2012). Furthermore, patients do not participate in the physical activity programs that are implemented in health care institutions due to transport difficulties, home and work obligations, and, in some cases, due to their reluctance to attend group exercise programs (Beswiski et al, 2004; Dalal et al, 2010). For these reasons, the adapted physical activity programs that can be performed by a patient in the home environment have been designed, and they are as safe and efficient as the institutionalized programs, as demonstrated in patients with coronary artery diseases (Dalal et al, 2010; Taylor et al, 2010; Dalal et al, 2007).

On the other hand, there are no appropriate records regarding the efficiency and characteristics of 
the physical activity programs performed in the home environment in patients with heart failure (Dalal et al, 2012). Also, there is a lack of research in regard to the optimal dosage and type of physical activity which will correspond to the aspects of safety and efficacy of such program performed in the home environment.

In 2010, we published the study aiming to define the effect of aerobic training compared to strength training in the patients with chronic heart failure (Jakovljevic et al, 2010). The results have shown that both interventions were safe and there were no negative consequences for patients. Nevertheless, the aerobic exercise program proved to be more efficient in regard to the improvement of functional capacity and cardiac function.

The previous studies evaluating the effects of physical activity have shown that the physical activity programs which are more frequent ( $\geq 5$ times a week) and of longer duration ( $\geq 30$ min per day) are more effective in regard to improving the quality of life and function in patients (Ress et al Taylor et al, 2014). Walking programs performed in the home environment and using pedometers to monitor a number of steps are effective ways to increase physical activity (Harris et al, 2017). Regarding the volume of physical activity, a large population study published in the Lancet journal confirmed that an increase in physical activity by 2000 steps per day in relation to the baseline (pre-intervention) level is related to a $10 \%$ reduction in the risk of cardiovascular diseases (Yates et al, 2014). Based on these facts, we developed a homebased physical activity intervention for patients with chronic heart failure (ACTIVE-at-HOME-HF) and have recently confirmed its feasibility and acceprability. The major findings of the study were presented at the European Heart Failure Association Congress in Paris in 2017 (Okwose et al, 2017). The study has shown that such an intervention is possible, safe and acceptable to patients, and it can lead to the improvement of quality of life and functional capacity. This single-center feasibility study was funded by the UK Health Ministry, the National Institute of Health Research (NIHR), in the amount of $£ 108,450$. A multi-center project aimed at defining the clinical- and cost-effectiveness of ACTIVE-AT-HOME-HF intervention in patients with chronic heart failure is under preparation. The estimated value of the project will amount to 680,000 pounds.

\section{Mechanic circulatory support in heart failure - Bridge-to-Recovery?}

Left Ventricular Assist Device (LVAD) is applied very successfully in clinical practice for the treatment of advanced heart failure. Initially, LVAD was designed to be used to preserve the life of a patient until a donor's heart becomes available for heart transplantation to be performed ("bridge-to-transplantation"). However, in the past several years, LVAD has been approved by the FDA to be used as a destination therapy ('bridge-to-destination'), which implies the fact that a patient with the implanted LVAD may be removed from a transplantation list since LVAD enables the patient to improve the quality of life and functional capacity (MacGowan et al, 2015; Lanneman \& Birks, 2014 In some cases, LVAD can lead to partial or complete cardiac recovery ('bridge-to-recovery') (Lanneman \& Birk, 2014). The LVAD implantation is associated with a whole range of histological, biochemical, anatomical, physiological, and haemodynamic changes observed in patients during a prolonged chronic left ventricular support using LVAD (Hall et al, 2011; Birks, 2013). In addition, a great number of clinical studies have confirmed that the LVAD implantation reduces mortality while improving the quality of life and functional capacity in patients (Laphor et al, 2010; Pagani et al, 2009). We have also shown that the use of LVAD can improve cardiac function (Jakovljevic et al, 2010a; Jakovljevic et al, 2010b). The cardiac function improvement can be achieved to the extent that it is possible to remove LVAD and avoid heart transplantation with a very good long-term outcome (Birks, 2010; Frazier et al, 2015). The recovery rate sufficient to remove LVAD has been observed in only $5-24 \%$ of patients (Birks, 2010). However, a special strategy including a combination of LVAD and medication using $\beta 2$-receptor agonists can stimulate the myocardium recovery and allow the LVAD explantation (removal) in a larger number of respondents than previously shown (Birks et al, 2006).

Since 2006, the multidisciplinary team to which the author of this paper belongs has aimed to improve clinical practice, patient outcomes and enhance scientific knowledge in the field of heart failure, the application of LVAD and, most importantly, to identify the most effective strategy which will lead to the myocardium recovery. In previous studies, we have shown that a unique measure of the overall cardiac function, the so-called cardiac power output (CPO) 
is the best indicator of heart failure severity and it is greatly differentiated between patient groups, such as advanced heart failure, LVAD patients, and those with the LVAD removed due to the recovery resulted in response to the chronic use of LVAD and the use of $\beta 2$-receptor agonists (Jakovljevic et al, 2010a). Furthermore, we have been dealing with the problem of identifying the physiological variables which can be used as an indicator of cardiac function in patients with LVAD (Jakovljevic et al, 2011), as well as with the problem of a haemodynamic response to the acute interruption of LVAD support in order to find an optimal strategy for cardiac function recovery evaluation in LVAD patients (Jakovljevic et al, 2010b).

Also, within our research program, we have made a longitudinal comparison of the functional capacity recovery, quality of life and physical activity between the patients who underwent cardiac transplantation and those who underwent LVAD implantation (Jakovljevic et al, 2014). The results of this study confirmed the effectiveness of LVAD therapy, but we also presented a new finding indicating that 6 months following LVAD implantation, functional capacity improvement compared to the patients who underwent heart transplantation.

Recently (in April 2017) we published the paper on the topic of 'LVAD - bridge to recovery' where we have shown for the first time that $40 \%$ of the patients with previously implanted LVAD can fully recover after LVAD explantation, thus demonstrating cardiac function which is equivalent to the cardiac function of a healthy person of the same age, who never had a heart disease (Jakovljevic et al, 2017). The paper was published in the best scientific journal of cardiology (Journal of the American College of Cardiology), which is the top-rated among 137 world journals available in this field with its impact factor of 19.9. The results of this study made a 'breaktrough' and were referred to in the news both in the UK and around the world. The scientific paper itself has been classified into a category including $5 \%$ of the papers that have attracted the greatest attention of the readers worldwide. Several British media interviews, including the $\mathrm{BBC}$, have been realized.

In order to pursue our research program in the field of mechancical circulatory support using LVAD, supported by the British Heart Foundation (BHF) and the European Research Council (ERC), we are preparing two research grant applications for a 5-year multidisciplinary research project in the total amount of $£ 3.2$ million in which the colleagues from Austria, Spain and Serbia will also participate in addition to those from the UK. The aim of this project is to develop a computer simulation model using clinical, molecular, histological, biochemical, physiological and genetic characteristics which will precisely I) identify the patients whose hearts will respond to LVAD implantation most adequately with the aim of complete recovery; II) define early recovery during LVAD therapy and help in deciding on the optimum time of LVAD explantation; and III) present a plan for optimal pharmacological therapy prior to, during and following LVAD therapy.

\section{CONCLUSION}

A multidisciplinary approach to scientific research is necessary in order to address the complex issues of today, including significant changes in the population demographic structure which represent one of the biggest challenges in the fields of the population's health, health care systems, economic and social achievements. In this paper, the findings of the research conducted by the multidisciplinary team have been presented with an emphasis on understanding structural and functional changes in cardiovascular system and the role of physical activity in preserving function and mortality prevention. Additionally, a research program in the field of heart failure has been described, from the improvement of heart failure diagnosis, the role of physical activity in improving the function and quality of life in patients, to the effects of left ventricular assist devices on recovery in advanced heart failure. Among others, our most recent and most important studyfindings have been presented, which has indicated that a significant number of patients with progressive heart failure can be completely recovered by applying a combination of mechanical circulatory support and adequate medicament therapy. 


\section{REFFERENCES}

1. Berry, J.D., Pandey, A, Gao, A., Leonard, D., Farzaneh-Far, R., Ayers, C., et al. (2013). Physical fitness and risk for heart failure and coronary artery disease. Circulation. Heart failure, 6:627-634.

2. Beswick, A.D., Rees, K., Griebsch, I., Taylor, F.C., Burke, M., West, R.R., et al (2004). Provision, uptake and cost of cardiac rehabilitation programmes: Improving services to under-represented groups. Health Technol Assess, 8:iii-iv, ix-x, 1-152.

3. Birks, E.J., Tansley, P.D., Hardy, J., George, R.S., Bowles, C.T., Burke, M., et al (2006). Left ventricular assist device and drug therapy for the reversal of heart failure. $N$ Engl J Med, 355:1873-1884.

4. Birks, E.J. (2010). Myocardial recovery in patients with chronic heart failure: Is it real? J Card Surg, 25:472-477.

5. Birks, E.J. (2013). Molecular changes after left ventricular assist device support for heart failure. Circ Res, 113:777-791.

6. Blair, S.N., Kohl, H.W., 3rd, Barlow, C.E., Paffenbarger, R.S., Jr., Gibbons, L.W., Macera, C.A. (1995). Changes in physical fitness and all-cause mortality. A prospective study of healthy and unhealthy men. Jama, 273:1093-1098.

7. Burkhoff, D., Sayer, G., Doshi, D., Uriel, N. (2015). Hemodynamics of mechanical circulatory support. J Am Coll Cardiol, 66:2663-2674.

8. Chodzko-Zajko, W.J., Proctor, D.N., Fiatarone Singh, M.A., Minson, C.T., Nigg, C.R., Salem, G.J., et al. (2009). American college of sports medicine position stand. Exercise and physical activity for older adults. Med Sci Sports Exerc., 41:1510-1530.

9. Chomistek, A.K., Manson, J.E., Stefanick, M.L., Lu, B., Sands-Lincoln, M., Going, S.B., et al.(2013). The relationship of sedentary behavior and physical activity to incident cardiovascular disease: Results from the women's health initiative. Journal of the American College of Cardiology, 2346-2354.

10. Commission, H. (2007).Pushing the boundaries: Improving services for people with heart failure. Comission for healh care audit \& inspection: London.

11. Dalal, H.M., Evans, P.H., Campbell, J.L., Taylor, R.S., Watt, A., Read, K.L., et al (2007). Homebased versus hospital-based rehabilitation after myocardial infarction: A randomized trial with preference arms--cornwall heart attack rehabilitation management study (charms). International journal of cardiology, 119:202-211

12. Dalal, H.M., Wingham, J., Palmer, J., Taylor, R., Petre, C., Lewin, R. (2012). Why do so few patients with heart failure participate in cardiac rehabilitation? A cross-sectional survey from england, wales and northern ireland. BMJ open, 2:e000787

13. Dalal, H.M., Zawada, A., Jolly, K., Moxham, T., Taylor, R.S. (2010). Home based versus centre based cardiac rehabilitation: Cochrane systematic review and meta-analysis. BMJ, 340:b5631.

14. Davies, E.J., Moxham, T., Rees, K., Singh, S., Coats, A.J., Ebrahim, S., et al (2010). Exercise based rehabilitation for heart failure. The Cochrane database of systematic reviews, CD003331.

15. Fonseca, C. (2006). Diagnosis of heart failure in primary care. Heart Fail Rev.11:95-107.

16. Frazier, O.H., Baldwin, A.C., Demirozu, Z.T., Segura, A.M., Hernandez, R., Taegtmeyer, H., et al (2015). Ventricular reconditioning and pump explantation in patients supported by continuous-flow left ventricular assist devices. J Heart Lung Transplant, 34:766-772.

17. Fuat, A., Hungin, A.P., Murphy, J.J. (2003). Barriers to accurate diagnosis and effective management of heart failure in primary care: Qualitative study. BMJ. 326:196.

18. Hall, J,L, Fermin, D.R., Birks, E.J., Barton, P.J., Slaughter, M., Eckman, P., et al (2011). Clinical, molecular, and genomic changes in response to a left ventricular assist device. J Am Coll Cardiol, 57:641-652.

19. Harper, S., Walport, M. (2016).Future of an Ageing Population. UK Department of Health.

20. Harris, T., Kerry, S.M., Limb, E.S., Victor, C.R., Iliffe, S., Ussher, M., et al (2017). Effect of a primary care walking intervention with and without nurse support on physical activity levels in 45- to 75-year-olds: The pedometer and consultation evaluation (pace-up) cluster randomised clinical trial. PLoS medicine, 14:e1002210. 
21. Haykowsky, M.J., Liang, Y., Pechter, D., Jones, L.W., McAlister, F.A., Clark, A.M.. (2007). A meta-analysis of the effect of exercise training on left ventricular remodeling in heart failure patients: The benefit depends on the type of training performed. Journal of the American College of Cardiology, 49:2329-2336.

22. Hobbs, F.D., Doust, J., Mant, J., Cowie, M.R.. (2010). Heart failure: Diagnosis of heart failure in primary care. Heart, 96:1773-1777.

23. Hobbs, F.D., Roalfe, A.K., Davis, R.C., Davies, M.K., Hare, R. (2007). Prognosis of all-cause heart failure and borderline left ventricular systolic dysfunction: 5 year mortality follow-up of the echocardiographic heart of england screening study (echoes). European heart journal, 28:1128-1134.

24. Hollingsworth, K.G., Blamire, A.M., Keavney, B.D., Macgowan, G.A. (2012). Left ventricular torsion, energetics, and diastolic function in normal human aging. Am J Physiol Heart Circ Physio, 302:H885-892.

25. Houghton, D., Jones, T.W., Cassidy, S., Siervo. M., MacGowan, G.A., Trenell, M.I., et al. (2016). The effect of age on the relationship between cardiac and vascular function. Mechanisms of ageing and development, 153:1-6.

26. Jakovljevic, D.G., Birks, E.J., George, R.S., Trenell, M.I., Seferovic, P.M., Yacoub, M.H., et al (2011). Relationship between peak cardiac pumping capability and selected exercise-derived prognostic indicators in patients treated with left ventricular assist devices. Eur J Heart Fail, 13:992-999.

27. Jakovljevic, D.G., Donovan, G., Nunan, D., McDonagh, S., Trenell, M.I., Grocott-Mason, R., et al (2010). The effect of aerobic versus resistance exercise training on peak cardiac power output and physical functional capacity in patients with chronic heart failure. International journal of cardiology, 145:526-528.

28. Jakovljevic, D.G., George, R.S., Donovan, G., Nunan, D., Henderson, K., Bougard, R.S., et al (2010a). Comparison of cardiac power output and exercise performance in patients with left ventricular assist devices, explanted (recovered) patients, and those with moderate to severe heart failure. Am J Cardiol, 105:1780-1785.
29. Jakovljevic, D.G., George R.S., Nunan D., Donovan, G., Bougard, R.S., Yacoub, M.H., et al (20106). The impact of acute reduction of continuous-flow left ventricular assist device support on cardiac and exercise performance. Heart, 96:1390-1395.

30. Jakovljevic, D.G., McDiarmid, A., Hallsworth, K., Seferovic, P.M., Ninkovic, V.M., Parry, G., et al (2014). Effect of left ventricular assist device implantation and heart transplantation on habitual physical activity and quality of life. Am J Cardiol, 114:88-93.

31. Jakovljevic, D.G., Moore, S., Hallsworth, K., Fattakhova, G., Thoma, C., Trenell, M.I. (2012). Comparison of cardiac output determined by bioimpedance and bioreactance methods at rest and during exercise. Journal of clinical monitoring and computing, 26:63-68.

32. Jakovljevic, D.G., Papakonstantinou, L., Blamire, A,M., MacGowan, G.A., Taylor, R., Hollingsworth, K.G., et al. (2015). Effect of physical activity on age-related changes in cardiac function and performance in women. Circ Cardiovasc Imaging, 8.

33. Jakovljevic, D.G., Trenell, M.I., MacGowan, G.A. (2014). Bioimpedance and bioreactance methods for monitoring cardiac output. Best Practice \& Research Clinical Anaesthesiology, 28:381-394

34. Jakovljevic, D.G., Yacoub, M.H., Schueler, S., MacGowan, G.A., Velicki, L., Seferovic, P.M., et al (2017). Left ventricular assist device as a bridge to recovery for patients with advanced heart failure. Journal of the American College of Cardiology, 69:1924-1933.

35. Jakovljevic, D.G. (2017). Physical activity and cardiovascular aging: Physiological and molecular insights. Experimental gerontology. In press.

36. Jehn, M., Schmidt-Trucksass, A., Schuster, T., Weis, M., Hanssen. H, Halle. M,, et al (2009). Daily walking performance as an independent predictor of advanced heart failure: Prediction of exercise capacity in chronic heart failure. Am Heart, 157:292-298.

37. Jones, T.W., Houghton, D., Cassidy, S., MacGowan, G.A., Trenell, M.I., Jakovljevic, D.G. (2015). Bioreactance is a reliable method for estimating cardiac output at rest and during exercise. British journal of anaesthesia, 115:386-391. 
38. Khunti, K., Squire, I., Abrams, K.R., Sutton, A.J. (2004). Accuracy of a 12-lead electrocardiogram in screening patients with suspected heart failure for open access echocardiography: A systematic review and meta-analysis. European journal of heart failure, 6:571-576.

39. Lahpor, J., Khaghani, A., Hetzer, R., Pavie, A., Friedrich, I., Sander, K., et al (2010). European results with a continuous-flow ventricular assist device for advanced heart-failure patients. Eur $J$ Cardiothorac Surg, 37:357-361.

40. Lakatta, E.G., Levy, D. (2003). Arterial and cardiac aging: Major shareholders in cardiovascular disease enterprises: Part ii: The aging heart in health: Links to heart disease. Circulation, 107:346-354

41. Lenneman, A.J., Birks, E.J. (2014). Treatment strategies for myocardial recovery in heart failure. Curr Treat Options Cardiovasc Med, 16:287.

42. Lewinter, C., Doherty, P., Gale, C.P., Crouch, S., Stirk, L., Lewin, R.J., et al (2015). Exercise-based cardiac rehabilitation in patients with heart failure: A meta-analysis of randomised controlled trials between 1999 and 2013. European journal of preventive cardiology, 22:1504-1512.

43. MacGowan, G.A., Crossland, D.S., Hasan, A., Schueler, S. (2015). Considerations for patients awaiting heart transplantation-insights from the uk experience. J Thorac Dis, 7:527-531.

44. Mant, J., Doust, J., Roalfe, A., Barton, P., Cowie, M.R., Glasziou, P., et al (2009). Systematic review and individual patient data meta-analysis of diagnosis of heart failure, with modelling of implications of different diagnostic strategies in primary care. Health Technol Assess, 13:1-207.

45. Mezzani, A., Corra, U., Giannuzzi, P. (2008). Central adaptations to exercise training in patients with chronic heart failure. Heart Fail Rev, 13:13-20.

46. Nathania, M., Hollingsworth, K.G., Bates, M., Eggett, C., Trenell, M.I., Velicki, L., et al. (2017). Impact of age on the association between cardiac high-energy phosphate metabolism and cardiac power in women. Heart, 311275.

47. Njemanze, H., Warren, C., Eggett, C., MacGowan, G.A., Bates, M.G., Siervo, M., et al. (2016). Age-related decline in cardiac autonomic function is not attenuated with increased physical activity. Oncotarget, 1-8.
48. Okwose, N., Cassidy, S., Avery, L., O’Brien, N., Bailey, K., Skinner, J., MacGowan, G.A., Jakovljevic, D.G. (2017). Active-at-home: Haemodynamic effects of a novel, personalised, home-based physical activity intervention for chronic heart failure - a feasibility study. European Journal of Heart Failure, In Press.

49. Okwose, N.C., Chowdhury, S., Houghton, D., Trenell, M.I., Eggett, C., Bates, M., et al (2017). Comparison of cardiac output estimates by bioreactance and inert gas rebreathing methods during cardiopulmonary exercise testing. Clinical physiology and functional imaging, 1329-1337.

50. Pagani, F.D., Miller, L.W., Russell, S.D., Aaronson, K.D., John, R., Boyle, A.J., et al (2009). Extended mechanical circulatory support with a continuous-flow rotary left ventricular assist device. J Am Coll Cardiol, 54:312-321

51. Perkins, R.E., Hollingsworth, K.G., Eggett, C., MacGowan, G.A., Bates, M.G., Trenell, M.I., et al (2016). Relationship between bioreactance and magnetic resonance imaging stroke volumes. British journal of anaesthesia, 117:134-136.

52. Piepoli, M.F., Conraads, V., Corra, U., Dickstein, K., Francis, D.P., Jaarsma, T., et al (2011). Exercise training in heart failure: From theory to practice. A consensus document of the heart failure association and the european association for cardiovascular prevention and rehabilitation. European journal of heart failure, 13:347-357.

53. Ponikowski, P., Voors, A.A., Anker, S.D., Bueno, H., Cleland. J,G., Coats, A.J., et al(2016).Esc guidelines for the diagnosis and treatment of acute and chronic heart failure: The task force for the diagnosis and treatment of acute and chronic heart failure of the european society of cardiology (esc) developed with the special contribution of the heart failure association (hfa) of the esc. European heart journal, 37:2129-2200.

54. Rees, K., Taylor, R.S., Singh, S., Coats, A.J., Ebrahim, S. (2004). Exercise based rehabilitation for heart failure. The Cochrane database of systematic reviews, CD003331.

55. Research Councils UK (2017). www.rcuk.ac.uk

56. Roberts, E., Ludman, A.J., Dworzynski, K., Al-Mohammad, A., Cowie, M.R., McMurray, J.J., et al (2015). The diagnostic accuracy of the natriuretic peptides in heart failure: Systematic review and diagnostic meta-analysis in the acute care setting. BMJ, 350:h910. 
57. Sato, N., Origuchi, H., Yamamoto, U., Takanaga, Y., Mohri, M. (2012). The importance of daily physical activity for improved exercise tolerance in heart failure patients with limited access to centre-based cardiac rehabilitation. Exp Clin Cardiol, 17:121-124.

58. Shih, H., Lee, B., Lee, R.J., Boyle, A.J. (2011). The aging heart and post-infarction left ventricular remodeling. Journal of the American College of Cardiology, 57:9-17.

59. Shiroma, E.J., Lee, I.M. (2010). Physical activity and cardiovascular health: Lessons learned from epidemiological studies across age, gender, and race/ethnicity. Circulation, 122:743-752.

60. Talbot, L., Metter, E.J., Fleg, J.L. (2000). Leisure-time physical activities and their relationship to cardiorespiratory fitness in healthy men and women 18-95 years old. Med Sci Sports Exerc, 32:417-425.

61. Talbot, L.A., Morrell, C.H., Fleg, J.L., Metter, E.J. (2007). Changes in leisure time physical activity and risk of all-cause mortality in men and women: The baltimore longitudinal study of aging. Prev Med, 45:169-176.

62. Tanaka, H., Desouza, C.A., Jones, P.P., Stevenson, E.T., Davy, K.P., Seals, D.R. (1997). Greater rate of decline in maximal aerobic capacity with age in physically active vs. Sedentary healthy women. $J$ Appl Physiol, 83:1947-1953.
63. Taylor, R.S., Dalal, H., Jolly, K., Moxham, T., Zawada, A. (2010). Home-based versus centre-based cardiac rehabilitation. The Cochrane database of systematic reviews, CD007130.

64. Taylor, R.S., Sagar, V.A., Davies, E.J., Briscoe, S., Coats, A.J., Dalal, H., et al (2014). Exercise-based rehabilitation for heart failure. The Cochrane database of systematic reviews, CD003331.

65. Tudor-Locke, C., Bassett, D.R., Jr.(2004). How many steps/day are enough? Preliminary pedometer indices for public health. Sports Med, 34:1-8.

66. Walsh, J.T., Charlesworth, A., Andrews, R., Hawkins, M., Cowley, A.J. (1997). Relation of daily activity levels in patients with chronic heart failure to long-term prognosis. The American journal of cardiology, 79:1364-1369.

67. Wilson, T.M., Tanaka, H. (2000). Meta-analysis of the age-associated decline in maximal aerobic capacity in men: Relation to training status. $A m \mathrm{~J}$ Physiol Heart Circ Physiol, 278:H829-834.

68. Yates, T., Haffner, S.M, Schulte, P.J., Thomas, L., Huffman, K.M., Bales, C.W., et al (2014). Association between change in daily ambulatory activity and cardiovascular events in people with impaired glucose tolerance (navigator trial): A cohort analysis. Lancet, 383:1059-1066.

69. Youngblood, D. (2007). Interdisciplinary studies and the bridging disciplines: A matter of process. Journal of Research Practice, 3:18-24. 


\title{
PERSONAL- UND SYSTEMNOTWENDIGKEITEN EINER ERFOLGREICHEN FORSCHUNGSKARRIERE IM BEREICH DER MULTIDISZIPLINÄREN WISSENSCHAFTEN - PERSÖNLICHER ÜBERBLICK / RÜCKBLICK
}

\begin{abstract}
Zusammenfassung
Ein multidisziplinärer Zugang zu wissenschaftlicher Forschungsarbeit ist notwendig, um die Antwort auf komplexe Fragen im Bereich medizinischer und biomedizinischer Wissenschaften zu finden. Der Verfasser dieser Arbeit ist Mitglied und Koordinator eines multidisziplinären Teams, das aus Fachärzten, Allgemeinärzten, Molekularbiologen, Biochemikern, Physiologen, Psychologen, Physiotherapeuten, Bioinfomatikern, Physikern, Statistikern und Ingenieuren zusammengestellt ist. Dieses Team realisiert ein mehrjähriges Programm in Bereichen der Erforschung von kardiovaskulären Alterungsprozessen, Herzinsuffizienz und körperlicher Aktivität. Ziel dieses Überblicksartikels ist es, die Ergebnisse einiger wissenschaftlicher Forschungsprojekte und Arbeiten des beschriebenen multidisziplinären Teams vorzustellen, die in angesehenen internationalen Zeitschriften in Bereichen: 1) der Erforschung von Alterungsprozessen von kardiovaskulären Systemen und des Einflusses von physiologischen Prozessen auf diese Systeme und II) der Verbesserung der Diagnose und Behandlung von Herzinsuffizienz in primärem und sekundärem Gesundheitsschutz veröffentlicht wurden. Die vorgestellten Untersuchungen und ihre Ergebnisse sind auf die Verbesserung der allgemeinen Gesundheit und der funktionalen Kapazität der Patienten einerseits, und auf die Verbesserung des Gesunheitsschutzsystems und der klinischen Praxis andererseits orientiert. Außer einer kurzen Vorstellung der wissenschaflichen Arbeiten und ihrer Ergebnisse, beschreibt dieser Überblicksartikel auch den Applizierungsprozess, die Planung und die Sicherstellung von finanziellen Mitteln für die wissenschaftliche Forschungsarbeit im Hochschulsystem des Vereinigten Königreichs von Großbrittanien.
\end{abstract}

Schlüsselwärter: MULTIDISZIPLINÄRER ZUGANG / BIOMEDIZINISCHE WISSENSCHAFTEN / KARDIOVASKULÄRE KRANKHEITEN / HERZINSUFFIZIENZ / KÖRPERLICHE ÜBUNGEN / FORSCHUNG / GROßBRITTANIEN

Received: 01.11.2017

Accepted: 05.12.2017 


\title{
ПЕРСОНАЛНЕ И СИСТЕМСКЕ НЕОПХОДНОСТИ УСПЕШНЕ ИСТРАЖИВАЧКЕ КАРИЈЕРЕ У ДОМЕНУ МУЛТИДИСЦИПЛИНАРНИХ БИОМЕДИЦИНСКИХ НАУКА - ЛИЧНИ ПРЕГЛЕД / ОСВРТ
}

\author{
Ђорђе Јаковљевић \\ Центар за кардиоваскуларна истраживања, Факултет Медицинских наука, \\ Универзитет у Њу Кастлу и Болница Њукастл на Тајну, НХС Фонд поверења, Велика Британија
}

\begin{abstract}
САЖЕТАК
Мултидисциплинарни приступ научно- истраживачком раду је неопходан да би се пронашао одговор на комплексна питања у областима медицинских и биомедицинских наука. Аутор овог рада припада и координира рад мултидисциплинарног тима састављеног од лекара специјалиста, лекара опште праксе, молекуларних биолога, биохемичара, физиолога, психолога, физиотерапеута, биоинформатичара, физичара, статистичара и инжењера. Овај тим води вишегодишњи истраживачки програм у областима изучавања процеса кардиоваскуларног старења, срчане слабости и физичке активности. Циљ овог прегледног чланка је представљање резултата неколико научно-истраживачких пројеката и радова објављених у угледним међународним часописима описаног мултидисциплинарног тима у областима: I) изучавања процеса старења кардиоваскуларног система и утицаја физиолошких процеса на исти, и II) побољшање дијагнозе и третмана срчане слабости у примарној и секундарној здравственој заштити. Представљена истраживања и њихови резултати су усмерени на побољшање општег здравља и функционалног капацитета пацијената са једне стране, и побољшање система здравствене заштите и клиничке праксе са друге стране. Поред тога што су укратко представљени научни радови и њихови резултати, овај прегледни чланак такође описује процесе апликација, начине планирања и обезбеђивања финансијских средстава за научно-истраживачки рад у високо-образовном систему Уједињеног Краљевства Велике Британије.
\end{abstract}

КљУчНе речи: МУЛТИДИСЦИПЛИНАРНИ ПРИСТУП / БИОМЕДИЦИНСКЕ НАУКЕ / КАРДИОВАСКУЛАРНЕ БОЛЕСТИ / СРЧАНА СЛАБОСТ/ ФИЗИЧКО ВЕЖБАЮЕ / ИСТРАЖИВАЮА/ ВЕЛИКА БРИТАНИЈА

\section{УВОД}

Проналажење одговора и решења на комплексна истраживачка питања у сферама медицинских и биомедицинских наука захтева мутидисциплинарни приступ. Мултидисциплинарност подразумева укључење (ангажовање) неколико академских дисциплина и стручних специјализација у приступу решавања претходно дефинисаног проблема (Youngblood, 2007) Нови, мултидисциплинарни приступи су неопходни за решавање многих, ако не и свих, научно-истраживачких и економско-социјалних изазова данашњице. Веома је јасно да само такав приступ може допринети иновацијама које промовишу економски развој, психо-физичко и социјално благостање грађана и система како развијених земаља тако и оних које су у развоју. Изузетан је пример Британског савета за научно-истраживачки рад са годишњим буџетом од преко 3 милијарде енглеских фунти које инвестира у мултидисциплинарне пројекте, интегришући рад седам научно-истраживачких одсека, који између осталих укључују медицинске, биотехнолошке, биолошке, инжењерске, физичке, економске, социјалне и технолошке науке (Harper; Walport, 2016)

Један од највећих изазова човечанства у наредних 30-50 година биће драстична промена у 
демографској структури становништва која предвиђа да ће до 2050. године једна од три особе бити $>65$ година старости, и једна од 10 особа бити $>80$ година старости.( Lakatta, Levy, 2003) Ове промене имају изузетан економско-социјални значај. Одговор на демографске промене ће захтевати адаптацију многих аспеката живота људи, укључујући начин на који радимо, водимо рачуна, комуницирамо и „интерактујемо“ са другима, прилагођавамо непосредно окружење у коме живимо и радимо, учимо и користимо технологију. Да би се успешно адаптирали таквим околностима, неоходно је разумевање природе и импликације демографских промена, као и детаље самог биолошког процеса старења.

Са аспекта медицинских и биомедицинских наука неопходно је да разумемо молекулране, целуларне и физиолошке промене које директно утичу на процес старења људског организма. Као последица ових промена долази до опадања квалитета живота, функционалног капацитета, као и смањења прага настанка хроничних болести које доприносе повећаном степену морталитета и морбидности код старијих особа. Аутор овог чланка је део и вођа мултидисциплинарног тима састављеног од лекара специјалиста, лекара опште праксе, молекуларних биолога, биохемичара, физиолога, психолога, физиотерапеута, биоинформатичара, физичара, статистичара и инжењера.

Задатак овог мултидисциплинарног тима јесте да побољша разумевање процеса старења са посебним фокусом на кардиоваскуларне и метаболичке промене, и идентификује потенцијалне терапеутске фармаколошке и физиолошке интервенције које ће побољшати квалитет живота и функцију старијих људи, успоре процес старења, и утичу на превенцију настанка хроничних обољења.

Циљ овог прегледног чланка јесте да представи резултате неколико научно-истраживачких радова, описаног мултидисциплинарног тима, у областима: I) изучавања процеса старења кардиоваскуларног система и утицаја физиолошких интервенција на исти, и II) побољшање дијагнозе и третмана срчане слабости у примарној и секундарној здравственој заштити.

\section{Старење кардиоваскуларног система и фи- зичка активност}

Године старости појединца су главни фактор ризика за настанак кардиоваскуларних обољења која су водећи узрок смртности старијих људи у развијеним земљама (Harper, Walport, 2016). У одсуству клиничке хипертензије или дијагностикованог обољења кардиоваскуларног система, са процесом старења настају структуралне и функционалне промене на срцу и крвним судовима (Lakatta, Levy, 2003). Ове промене смањују праг за појаву клиничких симптома и знакова повезаних са кардиоваскуларним болестима (Shih et al, 2011). Једна од водећих неинвазивних метода за евалуацију структуре и функције кардиоваскуларног система јесте магнетна резонанца срца и крвних судова (Hollingsworth, 2012).

Физичка активност има веома важну улогу у превенцији и контроли кардиоваскуларних обољења (Chodzko-Zajko et al, 2009; Berry, 2013) Регуларна физичка активност умањује степен опште и кардиоваскуларне смртности између 30-40\% (Shiroma, Lee, 2010; Blair et al, 1995; Talbot et al, 2007). Са друге стране, особе које су физички неактивне показују 63\% већи ризик за развој кардиоваскуларних болести. (Chomistek, 2013). Иако физичика активност има веома важну улогу у одржавању општег здравља и кардиоваскуларне функције, са процесом старења долази до опадања степена физичке активности и кардиоваскуларне функције (Talbot, Metter, Fleg, 2000; Wilson \& Tanaka, 2000; Tanaka et al, 1997).

Премда редовна физичка активност може да умањи физиолошке, молекуларне и целуларне промене које су узрок процеса старења, као што смо недавно показали у прегледном чланку (Jakovljevic, 2017), даља истраживања су неопходна за дефинисање детаља интеракције између процеса старења, физиолошке функције и физичке активности. У претходној студији испитивали смо повезаност између параметара функције срца и крвних судова (артерија) у односу на године старости појединца (Houghton et al, 2016). Резултати су показали да је крутост артерија ('arterial stiffness') одличан показатељ функције срца код старијих, али не и код млађих особа.

Такође, потребно је утврдити молекуларне механизме као потенцијалне узроке слабљења функције срца током процеса старења. Студија коју смо објавили потврђује улогу енергетског капацитета срца (високо-енергетског фосфатног метаболизма мереног магнетном резонанцом) у улози очувања срчане функције код старијих особa (Nathania et al, 2017). Резултати ове студи- 
је утицали су на развој нових идеја и истраживачких пројеката који имају циљ да открију нове фармаколшке и физиолошке интервенције које умањују крутост артерија и/или повећавају енергетски капацитет срца како би се такође утицало на побољшање систолне и дијастолне функције миокарда.

Уобичајена дневна физичка активност може се објективно измерити коришћењем акцелерометара и педометара у истраживањима и клиничкој пракси. Према резултатима претходних истраживања, а на основу просечног броја корака које појединац направи, испитанике је могуће категорисати као 'недовољно физички активне' (<7,500 корака по дану) или 'веома физички активне' (>12,500 корака по дану) (Tudor-Locke , Bassett, 2004). Користећи овај приступ ми смо квантификовали утицај објективно мерене физичке активности на промене у срчаној функцији, структури и метаболизму које настају као последица физиолошког старења (Jakovljevic et al, 2015). У једноцентричној студији попречног пресека која је укључила 63 испитаника (жена), резултати су показали да је високи степен свакодневне физичке активности неопходан за очување метаболизма срца и функционалног капацитета представљеног кардио-респираторним фитнесом, тј. максималном потрошњом кисеоника. У другој студији смо пак показали да повишен ниво физичке активности има заправо веома мали ефекат на умањену аутономну функцију срца код старијих особа (Njemanze et al, 2016).

Поред описаних клиничких студија, такође водимо истраживачки програм базичних наука коришћењем експерименталних методаукључујући мишеве. Овај програм нам омогућава да коришћењем самог ткива срчаног мишића (миокарда), великих артерија, централног нервног система, скелетних мишића, и осталих органа дефинишемо молекуларне и целуларне механизме који су одговорни за смањење физиолошке функције услед старења, и омогуће идентификацију нових циљева развоја фармаколошких и физиолошких терапеутских стратегија. Посебно смо сконцентрисани да боље разумемо промене и улогу митохондрије, као јединствене али веома комплексне органеле одговорне за читав низ енергетских процеса који се дешавају на ћелијском нивоу, а одговорни су за адекватно функционисање самих ћелија, органа и организма.
Како бисмо објединили и синхронизовали научно -истраживачки рад у домену клиничких и базичних наука када је у питању изучавање процеса старења и утицаја физиолошких и фармаколошких утицаја на исти, 2015. године смо написали пројекат, аплицирали и добили финансијска средства од стране Британског савета за медицинска истраживања у вредности од 5.5 милиона енглеских фунти за период од 5 година (20162021. године) који омогућава истраживачки рад и функционисање Центра за проучавање процеса старења у коме аутор овог чланка води поље кардиоваскуларних истраживања.

СРЧАНА СЛАБОСТ - ОД
ПОБОЉШАҢА ДИЈАГНОЗЕ,
УТИЦАЈА ФИЗИЧКЕ
АКТИВНОСТИ НА ИСХОД
ПАЦИЈЕНАТА, ДО МЕХАНИЧКЕ
ЦИРКУЛАТОРНЕ ПОТПОРЕ И
ПОТПУНОГ ИЗЛЕЧЕЊА

\section{Рана дијагностика срчане слабости}

Срчана слабост или срчана инсуфицијенција је клинички синдром праћен симптомима и знаковима узрокованих структуралним и/или функционалним абнормалностима срца које резултирају смањењем минутног волумена срца у миру или током стреса Ponikowski et al, 2016). Преваленца и инциденца срчане слабости се линеарно повећава због промена у демографској структури и побољшања исхода код болести коронарних артерија. Преко 2\% пупулације старости $>45$ година има срчану слабост, а преваленца прелази $>10 \%$ код људи старијих од 70 година (Ponikowski et al, 2016). Срчана слабост је повезана са веома лошом прогнозом (5-годишњи морталитет износи чак $42 \%$ ), учесталом хоспитализацијом и високим медицинским трошковима (Hobbs et al, 2007).

Рана дијагноза срчане слабости је најважнија јер дозвољава имплементацију терапије која смањује смртност и морбидност, док побољшава квалитет живота и функционални капацитет пацијената (Ponikowski et al, 2016). Међутим, дијагноза је компликована и непрецизна посебно у раним фазама болести. Иако због симптома које осећају пацијенти траже помоћ лекара, многи од ових симптома и знакова не морају бити само повезани са смањеном функцијом срца, већ и 
са годинама старости, гојазношћу или респираторним проблемима (Mant et al, 2009). Лекари опште праксе имају кључну улогу у раној идентификацији срчане слабости (Hobbs et al, 2010). Ипак, медицинска истраживања показују да се срчана слабост у примарној заштити веома ретко идентификује, и пацијенти нису упућени на специјалистички преглед када је то оптимално, већ врло често у каснијим фазама болести.(Hobbs et al, 2010; Roberts et al 2015). Главни разлог такве тренутне ситуације јесте да је срчана слабост препозната као комплексно обољење презентовано са срчаном дисфункцијом, а лекари опште праксе немају приступ једноставним, релативно јефтиним методама, које могу применити у својој пракси за евалуацију срчане функције, које ће им помоћи да дијагностикују и прате срчану слабост (Fonseca 2006; Fuat, Hunigain, Murphy, 2003).

Поред тога што евалуирају симптоме и знакове, лекари опште праксе тренутно имају приступ (користе) електрокардиограм и анализирају биомаркере, као што је Б-type natriureticki peptide. Међутим дијагностичка прецизност обе методе је умањена (Roberts et al, 2015; Khunti et al, 2004). Смањена прецизност ових тестова утиче на закаснелу дијагностику и непрецизним упутима из примарне у секундарну заштиту који су веома скупи за систем здравстевне заштите (42 милона фунти годишње) и забрињавајући за саме пацијенте.

Ултразвук срца (ехокардиографија), која се изводи у секундарној заштити, и преглед специјалисте је референтна метода за дијагностиковање срчане слабости (Ponikowski et al, 2016). Међутим време чекања за ехокардиографски преглед може износити и до 12 недеља (Commission, 2007), што доводи до закаснеле дијагностике. Са друге стране $2 / 3$ пацијената упућених из примарне у секундарну заштиту на основу резултата биомаркера, симптома и знакова, немају потврђену дијагнозу срчане слабости након ехокардиографије и специјалистичког прегледа. Из овога се може видети да постоји огромна потреба за идентификацијом нових савремених дијагностичких метода које ће водити побољшању клиничке праксе у примарној заштити и самом добром исходу пацијената када је у питању рана идентификација (дијагноза) срчане слабости.

Имајући у виду наведене чињенице, ми смо развили једноставан, неинвазиван тест који под- разумева континуирано мерење срчане функције (минутног волумена срца) током мировања и током теста оптерећења (CORS, cardiac output response to stress test), коришћењем метода за процену функције срца базираног на процесуирању електричног сигнала (bioreactance), чију смо валидност и релиабилност потврдили у неколико независних студија (Jakovljević et al, 2012; Jakovljevic, Trenell \&MacGowan, 2014; Okwose et al, 2017; Perkins et al, 2016; Jones et al, 2015). CORS тест је развијен за потребе примарне заштите са циљем ране дијагнозе и побољшања прецизности упута из примарне у секундарну заштиту. Истраживачи програма, који је у току, фокусира се на дијагностичку прецизност (сензитивност и специфичност) CORS теста, његову прихватљивост од стране пацијената, лекара опште праксе и медицинских техничара. Иницијална фаза овог истраживачког програма је финансирана од стране Британског савета за медицинска истраживања (MRC) вредности 220.000 енглеских фунти за период 06/2016-03/2018. У сарадњи са директорима Департмана за истраживања у примарној заштити Универзитета у Оксфорду и Кембриџу, у припреми су апликације за Британски национални институт за истраживања у здрављу (NIHR) у вредности од 2.3 милиона енглеских фунти за петогодишњи истраживачки мулти-центрични програм чији је циљ потврда дијагностичке прецизности CORS тест-а на великом узорку испитаника, економска евалуација и имплементација CORS теста и клиничку праксу примарне заштите.

\section{Улога физичке активности у срчаној слабости}

Клиничке препоруке сврставају физичку активност интегрисану у програм рехабилитације као једну од главних компоненти контролисања срчане слабости Ponikowski et al, 2016). Мета-анализе показују да регуларна физичка активност побољшава функционални капацитет и квалитет живота, док истовремено утиче на смањење симптома и хоспитализације код пацијената са срчаном слабошћу (Davies et al, 2010; Piepoli at al, 2011; Lewinter et al, 2015) Такође, физичка активност може до одређене мере утицати на побољшање функције самог срца када је његова слабост већ дијагностикована (Haykowsky et al, 2007; Mezzani, Corra \& Giannuzzi, 2008). 
Иако су користи од физичке активности код срчане слабости јасно дефинисане, из клиничке праксе је познато да већина пацијената показује смањен степен редовне физичке активности (што је у директној вези са степеном морбидности и морталитета) (Walsh et al, 1997; Sato et al, 2012; Jehn et al, 2009). Упркос јасним препорукама, веома мали број пацијената са срчаном слабошћу $(<10 \%)$ учествује у програмима рехабилитације које организује систем здравстевене заштите због недостатка ресурса и директног искључења програма рехабилитације срчане слабости из финансијских уговора (Dalal et al, 2012). Такође, пацијенти не учествују у програмима физичке активности који се реализују у усатановама здравствене заштите због потешкоћа транспорта, кућних и пословних обавеза, и у неким случајевима због одбојности од похађања групних програма вежбања (Beswiski et al, 2004; Dalal et al, 2010). Из наведених разлога, адаптирани програми физичке активности које пацијент може да изведе у кућном окружењу су осмишљени, безбедни, ефикасни као и институционализовани програми, што је показано код пацијената са обољењима коронарних артерија Dalal et al, 2010; Taylor et al, 2010; Dalal et al, 2007).

Са друге стране, не постоји довољна евиденција када је у питању ефикасност и карактеристике програма физичке активности изведеног у кућном окружењу код пацијената са срчаном слабошћy (Dalal et al, 2012). Такође, недостају истраживања када је у питању оптимална доза и врста физичке активности која ће одговарати аспектима безбедности и ефикасности таквог програма изведеног у кућном окружењу.

У 2010. години објавили смо студију чији је циљ био да дефинише ефекат аеробног наспрам тренинга снаге код пацијената са хроничном срчаном слабошћу (Jakovljevic et al, 2010). Резултати су показали да су обе интервенције биле безбедне и да није било негативних последица за пацијенте. Ипак, програм аеробног вежбања се показао ефикаснијим када је у питању побољшање функционалног капацитета и функције срца.

Претходне студије које су оцењивале утицај ефеката физичке активности, показале су да су програми физичке активности који су учесталији ( $\geq 5$ пута недељно) и дужег трајања ( $\geq 30$ мин дневно) ефикаснији када су у питању побољшање квалитета живота и функције пацијената (Ress et al. 2004; Taylor et al, 2014). Програми ходања у кућ- ном окружењу и коришћење педометара за праћење броја корака су ефективни начини да се повећа физичка активност (Harris et al, 2017). Када је у питању количина (volume) физичке активности, велика популацијска студија објављена у Lancet часопису је потврдила да повећање активности за 2000 корака по дану у односу на основни (пре-интервенцијски) ниво је у вези са 10\% смањењем ризикаод кардиоваскуларних обољења (Yates et al, 2014). Базирано на овим чињеницама, реализован је програм физичке активности за пацијенте са хроничном срчаном слабошћу (ACTIVE-ат-HOME-HF) и представили резултате студије изводљивости на конгресу Европске асоцијације за срчану слабост у Паризу 2017. године (Okwose et al, 2017). Студија је показала да је таква интервенција могућа, безбедна и прихватљива за пацијенте, као и да може довести до побољшања квалитета живота и функционалног капацитета. Ова једноцентрична студија изводљивости је финансирана од стране Министарства здравља Велике Британије, Националног института за здравствена истраживања (NIHR) у вредности од $£ 108.450$ енглеских фунти. У припреми је мултицентрични пројекат који ће имати за циљ да дефинише клиничку и финансијску ефикасност ACTIVE-AT-HOME-HF интервенције код пацијената са хроничном срчаном слабошћу. Процењена вредност пројекта ће износити 680.000 фунти.

\section{Механичка циркулаторна потпора у срчаној слабости - Bridge-to-Recovery?}

Механички уређаји за помоћ рада леве срчане коморе (Left Ventricular Assist Device, LVAD) се веома успешно користе у клиничкој пракси за третман напредне фазе срчане слабости. Иницијално, LVAD је направљен да се користи како би очувао пацијента у животу док срце донора не постане доступно да би се обавила трансплантација срца ('bridge-to-transpalntation'). Међутим последњих неколико година LVAD је одобрен од стране FDA да се користи као дестинациона терапија ('bridge-to-destination') што подразумева чињеницу да пацијент са уграђеним (имплантираним) LVAD-ом може бити померен са листе за трансплантацију jep му LVAD омогућава побољшање квалитета живота и функционалног капацитета (MacGowan et al, 2015; Lanneman \& Birks, 2014 У неким слуцајевима, LVAD може довести до делимичног или потпуног опоравка срца ('bridge-to-recovery') 
(Lanneman \& Birk, 2014). Уградња LVAD-a је повезана са читавим низом хистолошких, биохемијских, анатомских, физиолошких, и хемодинамичких промена које су примећене код пацијената током продужене хроничне подршке раду леве срцчане коморе коришћењем LVAD-a (Hall et al, 2011; Birks, 2013). Такође, велики број клиничких студија је потрврдио да уградња LVAD-a смањује морталитет док побољшава квалитет живота у функционални капацитет пацијената (Laphor et al, 2010; Pagani et al, 2009). Такође смо показали да коришћење LVAD-а може побољшати функцију срца (Jakovljevic et al, 2010a; Jakovljevic et al, 2010b). Побољшање функције срца може бити постигнуто до те мере да је могуће извадити LVAD и избећи трансплантацију срца са веома добрим дугорочним исходом (Birks, 2010; Frazier et al, 2015). Степен опоравка довољног да би ce LVAD извадио је примећен код свега 5-24\% пацијената Birks, 2010). Међутим, посебна стратегија комбинације LVAD-a са медикаментном терапијом коришћењем $\beta 2$-рецептор агониста, може да стимулише опоравак миокарда и дозволи експлантациjy (уклањање) LVAD-а у већем броју испитаника него што је раније показано (Birks et al, 2006).

Од 2006. године мултидисцилинарни тим коме припада аутор овог рада имао је за циљ да унапреди клиничку праксу, исход пацијената и поспеши научна сазнања у области срчане слабости, коришћења LVAD-а и што је најважније иденификацији најефикасније стратегије која ће водити опоравку миокарда. У ранијим истраживањима смо показали да је јединствена мера целокупне срчане функције, тзв. снага минутног волумена срца (cardiac power output, CPO) најбољи показатељ степена срчане слабости и да се одлично разликује између група пацијената, као што су напредни степен срчане слабости, затим пацијената ca LVAD-ом, као и оних којима је LVAD извађен због насталог опоравка у одговору на хроничну употребу LVAD-a и коришћењем $\beta 2$-рецептор агониста (Jakovljevic et al, 2010a). Даље смо се бавили проблемом који од физиолошких варијабли може да се користи као показатељ срчане функције код пацијената са уграђеним LVAD-oм (Jakovljevic et al, 2011), као и проблемом хемодинамичког одговора на акутни прекид подршке LVAD-a са циљем да нађемо оптималну стратегију евалуације срчане функције код LVAD пацијената (Jakovljevic et al, 2010b).

Такође, у нашем истраживачком програму на- правили смо лонгитудинално поређење опоравка функционалног капацитета, квалитета живота и физичке активности између пацијената којима је урађена трансплантација срца са онима којима је уграђен LVAD (Jakovljevic et al, 2014). Резултати ове студије су потврдили ефикасност LVAD терапије, али такође смо представили ново сазнање да након 6 месеци од уградње LVAD-a долази до успореног побољшања функције у односу на пацијенте којима је урађена трансплантација срца.

Недавно (у априлу 2017. године) смо објавили рад на тему 'LVAD - bridge to recovery' у коме смо први пут показали да 40\% пацијената са протходно уграђеним LVAD-ом, може се потпуно опоравити и након експлантације LVAD-a, демонстрирајући функцију срца која је еквивалентна функцији срца здраве особе истих година старости, која никада није имала обољење срчаног мишића (Jakovljevic et al, 2017). Рад је објављен у најбољем научном часопису за кардиологију (Journal of the American College of Cardiology) који је са импакт фактором од 19.9, први од 137 светских часописа доспупних у овој области. Резултати ове студије су направили 'breaktrough' и цитирани су у вестима како у Великој Британији тако и широм света. Сам научни рад је сврстан у категорију од $5 \%$ радова који су привукли највећу пажњу читалаца глобално. Неколико интервијуа за британске медиије, укључујући ВВС су реализовани.

Да бисмо наставили истраживачки програм у области механике циркулаторне потпоре коришћењем LVAD-a, уз подршку Британске фондације за срце (BHF) и Европског истраживачгог савета (ERC), припремамо две апликације за 5-годишњи мултидисциплинарни истраживачки пројекат, укупне вредности од 3.2 милииона британских фунти у коме ће поред колега из Велике Британије, учествовати колеге из Аустрије, Шпаније и Србије. Циље пројекта је да коришћењем клиничких, молекуларних, хистолошких, биохемијских, физиолошких и генетских карактеристика развије компјутерски симулациони модел који ће веома прецизно I) идентификовати пацијенте чији ће срце најадекватније да одреагује на уградњу LVAD-a ca циљем поптуног опоравка; II) дефинисати рани опоравак током LVAD терапије и помоћи у доношењу одлуке о оптималном времену експлантације LVAD-a; и III) представити план оптималне фармаколошке терапије пре, током и након LVAD терапије. 


\section{ЗАКЉУЧАК}

Мултидисциплинарни приступ научно-истраживачком раду је неопходан да би се одговорило на комплексна питања данашњице, укључујући значнајне промене у демографској структури становништва које представљају један од највећих изазова у сферама здравља популације, система здравствене заштите, економских и социјалних постигнућа. У раду су представљени резултати истраживања мултидисциплинарног тима са фокусом на разумевање структуралних и функционалних промена кардиоваскуларног система и

\section{ЛИТЕРАТУРА}

1. Berry, J.D., Pandey, A, Gao, A., Leonard, D., Farzaneh-Far, R., Ayers, C., et al. (2013). Physical fitness and risk for heart failure and coronary artery disease. Circulation. Heart failure, 6:627-634.

2. Beswick, A.D., Rees, K., Griebsch, I., Taylor, F.C., Burke, M., West, R.R., et al (2004). Provision, uptake and cost of cardiac rehabilitation programmes: Improving services to under-represented groups. Health Technol Assess, 8:iii-iv, ix-x, 1-152.

3. Birks, E.J., Tansley, P.D., Hardy, J., George, R.S., Bowles, C.T., Burke, M., et al (2006). Left ventricular assist device and drug therapy for the reversal of heart failure. N Engl J Med, 355:1873-1884.

4. Birks, E.J. (2010). Myocardial recovery in patients with chronic heart failure: Is it real? J Card Surg, 25:472-477.

5. Birks, E.J. (2013). Molecular changes after left ventricular assist device support for heart failure. Circ Res, 113:777-791.

6. Blair, S.N., Kohl, H.W., 3rd, Barlow, C.E., Paffenbarger, R.S., Jr., Gibbons, L.W., Macera, C.A. (1995). Changes in physical fitness and all-cause mortality. A prospective study of healthy and unhealthy men. Jama, 273:1093-1098.

7. Burkhoff, D., Sayer, G., Doshi, D., Uriel, N. (2015). Hemodynamics of mechanical circulatory support. J Am Coll Cardiol, 66:2663-2674.

8. Chodzko-Zajko, W.J., Proctor, D.N., Fiatarone Singh, M.A., Minson, C.T., Nigg, C.R., Salem, G.J., et al. (2009). American college of sports medicine position stand. Exercise and physical activity for older adults. Med Sci Sports Exerc., 41:1510-1530. улогом физичке активности у очување функције и превенцији морталитета. Такође, описан је и програм истраживања у области срчане слабости, од побољшања дијагнозе срчане слабости, улоге физичке активности у побољшању функције и квалитета живота самих пацијената, до ефеката механичких уређаја за помоћ рада леве срчане коморе. Између осталих представљени су и резултати наше најновије и најзначајније студије која је показала да се значајан број пацијената са прогресивном срчаном слабошћу може потпуно излечити коришћењем комбинације механичке циркулаторне потпоре и адекватне медикаментне терапије.

9. Chomistek, A.K., Manson, J.E., Stefanick, M.L., Lu, B., Sands-Lincoln, M., Going, S.B., et al.(2013). The relationship of sedentary behavior and physical activity to incident cardiovascular disease: Results from the women's health initiative. Journal of the American College of Cardiology, 2346-2354.

10. Commission, H. (2007).Pushing the boundaries: Improving services for people with heart failure. Comission for healh care audit \& inspection: London.

11. Dalal, H.M., Evans, P.H., Campbell, J.L., Taylor, R.S., Watt, A., Read, K.L., et al (2007). Homebased versus hospital-based rehabilitation after myocardial infarction: A randomized trial with preference arms--cornwall heart attack rehabilitation management study (charms). International journal of cardiology, 119:202-211

12. Dalal, H.M., Wingham, J., Palmer, J., Taylor, R., Petre, C., Lewin, R. (2012). Why do so few patients with heart failure participate in cardiac rehabilitation? A cross-sectional survey from england, wales and northern ireland. BMJ open, 2:e000787

13. Dalal, H.M., Zawada, A., Jolly, K., Moxham, T., Taylor, R.S. (2010). Home based versus centre based cardiac rehabilitation: Cochrane systematic review and meta-analysis. BMJ, 340:b5631.

14. Davies, E.J., Moxham, T., Rees, K., Singh, S., Coats, A.J., Ebrahim, S., et al (2010). Exercise based rehabilitation for heart failure. The Cochrane database of systematic reviews, CD003331.

15. Fonseca, C. (2006). Diagnosis of heart failure in primary care. Heart Fail Rev.11:95-107. 
16. Frazier, O.H., Baldwin, A.C., Demirozu, Z.T., Segura, A.M., Hernandez, R., Taegtmeyer, H., et al (2015). Ventricular reconditioning and pump explantation in patients supported by continuous-flow left ventricular assist devices. $J$ Heart Lung Transplant, 34:766-772.

17. Fuat, A., Hungin, A.P., Murphy, J.J. (2003). Barriers to accurate diagnosis and effective management of heart failure in primary care: Qualitative study. BMJ. 326:196.

18. Hall, J,L,, Fermin, D.R., Birks, E.J., Barton, P.J., Slaughter, M., Eckman, P., et al (2011). Clinical, molecular, and genomic changes in response to a left ventricular assist device. J Am Coll Cardiol, 57:641-652.

19. Harper, S., Walport, M. (2016).Future of an Ageing Population. UK Department of Health.

20. Harris, T., Kerry, S.M., Limb, E.S., Victor, C.R., Iliffe, S., Ussher, M., et al (2017). Effect of a primary care walking intervention with and without nurse support on physical activity levels in 45 - to 75-year-olds: The pedometer and consultation evaluation (pace-up) cluster randomised clinical trial. PLoS medicine, 14:e1002210.

21. Haykowsky, M.J., Liang, Y., Pechter, D., Jones, L.W., McAlister, F.A., Clark, A.M.. (2007). A meta-analysis of the effect of exercise training on left ventricular remodeling in heart failure patients: The benefit depends on the type of training performed. Journal of the American College of Cardiology, 49:2329-2336.

22. Hobbs, F.D., Doust, J., Mant, J., Cowie, M.R.. (2010). Heart failure: Diagnosis of heart failure in primary care. Heart, 96:1773-1777.

23. Hobbs, F.D., Roalfe, A.K., Davis, R.C., Davies, M.K., Hare, R. (2007). Prognosis of all-cause heart failure and borderline left ventricular systolic dysfunction: 5 year mortality follow-up of the echocardiographic heart of england screening study (echoes). European heart journal, 28:1128-1134.

24. Hollingsworth, K.G., Blamire, A.M., Keavney, B.D., Macgowan, G.A. (2012). Left ventricular torsion, energetics, and diastolic function in normal human aging. Am J Physiol Heart Circ Physio, 302:H885-892.

25. Houghton, D., Jones, T.W., Cassidy, S., Siervo. M., MacGowan, G.A., Trenell, M.I., et al. (2016). The effect of age on the relationship between cardiac and vascular function. Mechanisms of ageing and development, 153:1-6.
26. Jakovljevic, D.G., Birks, E.J., George, R.S., Trenell, M.I., Seferovic, P.M., Yacoub, M.H., et al (2011). Relationship between peak cardiac pumping capability and selected exercise-derived prognostic indicators in patients treated with left ventricular assist devices. Eur J Heart Fail, 13:992-999.

27. Jakovljevic, D.G., Donovan, G., Nunan, D., McDonagh, S., Trenell, M.I., Grocott-Mason, R., et al (2010). The effect of aerobic versus resistance exercise training on peak cardiac power output and physical functional capacity in patients with chronic heart failure. International journal of cardiology, 145:526-528.

28. Jakovljevic, D.G., George, R.S., Donovan, G., Nunan, D., Henderson, K., Bougard, R.S., et al (2010a). Comparison of cardiac power output and exercise performance in patients with left ventricular assist devices, explanted (recovered) patients, and those with moderate to severe heart failure. Am J Cardiol, 105:1780-1785.

29. Jakovljevic, D.G., George R.S., Nunan D., Donovan, G., Bougard, R.S., Yacoub, M.H., et al (20106). The impact of acute reduction of continuous-flow left ventricular assist device support on cardiac and exercise performance. Heart, 96:1390-1395.

30. Jakovljevic, D.G., McDiarmid, A., Hallsworth, K., Seferovic, P.M., Ninkovic, V.M., Parry, G., et al (2014). Effect of left ventricular assist device implantation and heart transplantation on habitual physical activity and quality of life. Am J Cardiol, 114:88-93.

31. Jakovljevic, D.G., Moore, S., Hallsworth, K., Fattakhova, G., Thoma, C., Trenell, M.I. (2012). Comparison of cardiac output determined by bioimpedance and bioreactance methods at rest and during exercise. Journal of clinical monitoring and computing, 26:63-68.

32. Jakovljevic, D.G., Papakonstantinou, L., Blamire, A,M., MacGowan, G.A., Taylor, R., Hollingsworth, K.G., et al. (2015). Effect of physical activity on age-related changes in cardiac function and performance in women. Circ Cardiovasc Imaging, 8.

33. Jakovljevic, D.G., Trenell, M.I., MacGowan, G.A. (2014). Bioimpedance and bioreactance methods for monitoring cardiac output. Best Practice \& Research Clinical Anaesthesiology, 28:381-394

34. Jakovljevic, D.G., Yacoub, M.H., Schueler, S., MacGowan, G.A., Velicki, L., Seferovic, P.M., et al (2017). Left ventricular assist device as a bridge to recovery for patients with advanced heart fail- 
ure. Journal of the American College of Cardiology, 69:1924-1933.

35. Jakovljevic, D.G. (2017). Physical activity and cardiovascular aging: Physiological and molecular insights. Experimental gerontology. In press.

36. Jehn, M., Schmidt-Trucksass, A., Schuster, T., Weis, M., Hanssen. H, Halle. M, et al (2009). Daily walking performance as an independent predictor of advanced heart failure: Prediction of exercise capacity in chronic heart failure. Am Heart, 157:292-298.

37. Jones, T.W., Houghton, D., Cassidy, S., MacGowan, G.A., Trenell, M.I., Jakovljevic, D.G. (2015). Bioreactance is a reliable method for estimating cardiac output at rest and during exercise. British journal of anaesthesia, 115:386-391.

38. Khunti, K., Squire, I., Abrams, K.R., Sutton, A.J. (2004). Accuracy of a 12-lead electrocardiogram in screening patients with suspected heart failure for open access echocardiography: A systematic review and meta-analysis. European journal of heart failure, 6:571-576.

39. Lahpor, J., Khaghani, A., Hetzer, R., Pavie, A., Friedrich, I., Sander, K., et al (2010). European results with a continuous-flow ventricular assist device for advanced heart-failure patients. Eur J Cardiothorac Surg, 37:357-361.

40. Lakatta, E.G., Levy, D. (2003). Arterial and cardiac aging: Major shareholders in cardiovascular disease enterprises: Part ii: The aging heart in health: Links to heart disease. Circulation, 107:346-354

41. Lenneman, A.J., Birks, E.J. (2014). Treatment strategies for myocardial recovery in heart failure. Curr Treat Options Cardiovasc Med, 16:287.

42. Lewinter, C., Doherty, P., Gale, C.P., Crouch, S., Stirk, L., Lewin, R.J., et al (2015). Exercise-based cardiac rehabilitation in patients with heart failure: A meta-analysis of randomised controlled trials between 1999 and 2013. European journal of preventive cardiology, 22:1504-1512.

43. MacGowan, G.A., Crossland, D.S., Hasan, A., Schueler, S. (2015). Considerations for patients awaiting heart transplantation-insights from the uk experience. J Thorac Dis, 7:527-531.

44. Mant, J., Doust, J., Roalfe, A., Barton, P., Cowie, M.R., Glasziou, P., et al (2009). Systematic review and individual patient data meta-analysis of diagnosis of heart failure, with modelling of implications of different diagnostic strategies in primary care. Health Technol Assess, 13:1-207.
45. Mezzani, A., Corra, U., Giannuzzi, P. (2008). Central adaptations to exercise training in patients with chronic heart failure. Heart Fail Rev, 13:13-20.

46. Nathania, M., Hollingsworth, K.G., Bates, M., Eggett, C., Trenell, M.I., Velicki, L., et al. (2017). Impact of age on the association between cardiac high-energy phosphate metabolism and cardiac power in women. Heart, 311275.

47. Njemanze, H., Warren, C., Eggett, C., MacGowan, G.A., Bates, M.G., Siervo, M., et al. (2016). Age-related decline in cardiac autonomic function is not attenuated with increased physical activity. Oncotarget, 1-8.

48. Okwose, N., Cassidy, S., Avery, L., O'Brien, N., Bailey, K., Skinner, J., MacGowan, G.A., Jakovljevic, D.G. (2017). Active-at-home: Haemodynamic effects of a novel, personalised, home-based physical activity intervention for chronic heart failure - a feasibility study. European Journal of Heart Failure, In Press.

49. Okwose, N.C., Chowdhury, S., Houghton, D., Trenell, M.I., Eggett, C., Bates, M., et al (2017). Comparison of cardiac output estimates by bioreactance and inert gas rebreathing methods during cardiopulmonary exercise testing. Clinical physiology and functional imaging, 1329-1337.

50. Pagani, F.D., Miller, L.W., Russell, S.D., Aaronson, K.D., John, R., Boyle, A.J., et al (2009). Extended mechanical circulatory support with a continuous-flow rotary left ventricular assist device. J Am Coll Cardiol, 54:312-321

51. Perkins, R.E., Hollingsworth, K.G., Eggett, C., MacGowan, G.A., Bates, M.G., Trenell, M.I., et al (2016). Relationship between bioreactance and magnetic resonance imaging stroke volumes. British journal of anaesthesia, 117:134-136.

52. Piepoli, M.F., Conraads, V., Corra, U., Dickstein, K., Francis, D.P., Jaarsma, T., et al (2011). Exercise training in heart failure: From theory to practice. A consensus document of the heart failure association and the european association for cardiovascular prevention and rehabilitation. European journal of heart failure, 13:347-357.

53. Ponikowski, P., Voors, A.A., Anker, S.D., Bueno, H., Cleland. J,G., Coats, A.J., et al(2016).Esc guidelines for the diagnosis and treatment of acute and chronic heart failure: The task force for the diagnosis and treatment of acute and chronic heart failure of the european society of cardiology (esc)developed with the special contribution of 
the heart failure association (hfa) of the esc. European heart journal, 37:2129-2200.

54. Rees, K., Taylor, R.S., Singh, S., Coats, A.J., Ebrahim, S. (2004). Exercise based rehabilitation for heart failure. The Cochrane database of systematic reviews, CD003331.

55. Research Councils UK (2017). www.rcuk.ac.uk

56. Roberts, E., Ludman, A.J., Dworzynski, K., Al-Mohammad, A., Cowie, M.R., McMurray, J.J., et al (2015). The diagnostic accuracy of the natriuretic peptides in heart failure: Systematic review and diagnostic meta-analysis in the acute care setting. BMJ, 350:h910.

57. Sato, N., Origuchi, H., Yamamoto, U., Takanaga, Y., Mohri, M. (2012). The importance of daily physical activity for improved exercise tolerance in heart failure patients with limited access to centre-based cardiac rehabilitation. Exp Clin Cardiol, 17:121-124.

58. Shih, H., Lee, B., Lee, R.J., Boyle, A.J. (2011). The aging heart and post-infarction left ventricular remodeling. Journal of the American College of Cardiology, 57:9-17.

59. Shiroma, E.J., Lee, I.M. (2010). Physical activity and cardiovascular health: Lessons learned from epidemiological studies across age, gender, and race/ethnicity. Circulation, 122:743-752.

60. Talbot, L., Metter, E.J., Fleg, J.L. (2000). Leisure-time physical activities and their relationship to cardiorespiratory fitness in healthy men and women 18-95 years old. Med Sci Sports Exerc, 32:417-425.

61. Talbot, L.A., Morrell, C.H., Fleg, J.L., Metter, E.J. (2007). Changes in leisure time physical activity and risk of all-cause mortality in men and women: The baltimore longitudinal study of aging. Prev Med, 45:169-176.
62. Tanaka, H., Desouza, C.A., Jones, P.P., Stevenson, E.T., Davy, K.P., Seals, D.R. (1997). Greater rate of decline in maximal aerobic capacity with age in physically active vs. Sedentary healthy women. $J$ Appl Physiol, 83:1947-1953.

63. Taylor, R.S., Dalal, H., Jolly, K., Moxham, T., Zawada, A. (2010). Home-based versus centre-based cardiac rehabilitation. The Cochrane database of systematic reviews, CD007130.

64. Taylor, R.S., Sagar, V.A., Davies, E.J., Briscoe, S., Coats, A.J., Dalal, H., et al (2014). Exercise-based rehabilitation for heart failure. The Cochrane database of systematic reviews, CD003331.

65. Tudor-Locke, C., Bassett, D.R., Jr.(2004). How many steps/day are enough? Preliminary pedometer indices for public health. Sports Med, 34:1-8.

66. Walsh, J.T., Charlesworth, A., Andrews, R., Hawkins, M., Cowley, A.J. (1997). Relation of daily activity levels in patients with chronic heart failure to long-term prognosis. The American journal of cardiology, 79:1364-1369.

67. Wilson, T.M., Tanaka, H. (2000). Meta-analysis of the age-associated decline in maximal aerobic capacity in men: Relation to training status. Am J Physiol Heart Circ Physiol, 278:H829-834.

68. Yates, T., Haffner, S.M, Schulte, P.J., Thomas, L., Huffman, K.M., Bales, C.W., et al (2014). Association between change in daily ambulatory activity and cardiovascular events in people with impaired glucose tolerance (navigator trial): A cohort analysis. Lancet, 383:1059-1066.

69. Youngblood, D. (2007). Interdisciplinary studies and the bridging disciplines: A matter of process. Journal of Research Practice, 3:18-24. 


\title{
PERSONAL- UND SYSTEMNOTWENDIGKEITEN EINER ERFOLGREICHEN FORSCHUNGSKARRIERE IM BEREICH DER MULTIDISZIPLINÄREN WISSENSCHAFTEN - PERSÖNLICHER ÜBERBLICK / RÜCKBLICK
}

\begin{abstract}
Zusammenfassung
Ein multidisziplinärer Zugang zu wissenschaftlicher Forschungsarbeit ist notwendig, um die Antwort auf komplexe Fragen im Bereich medizinischer und biomedizinischer Wissenschaften zu finden. Der Verfasser dieser Arbeit ist Mitglied und Koordinator eines multidisziplinären Teams, das aus Fachärzten, Allgemeinärzten, Molekularbiologen, Biochemikern, Physiologen, Psychologen, Physiotherapeuten, Bioinfomatikern, Physikern, Statistikern und Ingenieuren zusammengestellt ist. Dieses Team realisiert ein mehrjähriges Programm in Bereichen der Erforschung von kardiovaskulären Alterungsprozessen, Herzinsuffizienz und körperlicher Aktivität. Ziel dieses Überblicksartikels ist es, die Ergebnisse einiger wissenschaftlicher Forschungsprojekte und Arbeiten des beschriebenen multidisziplinären Teams vorzustellen, die in angesehenen internationalen Zeitschriften in Bereichen: 1) der Erforschung von Alterungsprozessen von kardiovaskulären Systemen und des Einflusses von physiologischen Prozessen auf diese Systeme und II) der Verbesserung der Diagnose und Behandlung von Herzinsuffizienz in primärem und sekundärem Gesundheitsschutz veröffentlicht wurden. Die vorgestellten Untersuchungen und ihre Ergebnisse sind auf die Verbesserung der allgemeinen Gesundheit und der funktionalen Kapazität der Patienten einerseits, und auf die Verbesserung des Gesunheitsschutzsystems und der klinischen Praxis andererseits orientiert. Außer einer kurzen Vorstellung der wissenschaflichen Arbeiten und ihrer Ergebnisse, beschreibt dieser Überblicksartikel auch den Applizierungsprozess, die Planung und die Sicherstellung von finanziellen Mitteln für die wissenschaftliche Forschungsarbeit im Hochschulsystem des Vereinigten Königreichs von Großbrittanien.
\end{abstract}

Schlüsselwärter: MULTIDISZIPLINÄRER ZUGANG / BIOMEDIZINISCHE WISSENSCHAFTEN / KARDIOVASKULÄRE KRANKHEITEN / HERZINSUFFIZIENZ / KÖRPERLICHE ÜBUNGEN / FORSCHUNG / GROßBRITTANIEN

Примљен: 01.11.2017

Прихваћен: 05.12.2017 